\title{
HUBUNGAN HUKUM KEMITRAAN DALAM LINKAGE PROGRAM PERBANKAN SYARI'AH
}

\author{
Johan Arifin, IAIN Walisongo Semarang
}

\begin{abstract}
Linkage program is a strategy that aims to empower and provide access to capital for small and medium enterprises (UMKM) through the involvement of participation in the financial industry. It is based on the fact that BPR / S or Shari'ah microfinance institutions like. Baitul Maal Wa Tamwil (BMT) sometimes have problems in mobilizing public sector funds. While commercial banks on the other hand tend to have excess funds that the public sector (over liquidity) but space is limited to micro business reach its movement. In other words, that the benefits of this program, commercial banks have easy access to UMKM and $B M T$ benefit from the availability of funds to be distributed to the debtor, with due regard to the risk management process so as not to encourage an increase in the ratio of financing problems (non-performing financing).
\end{abstract}

Keywords : Kemitraan, linkage, UMKM

\section{Pendahuluan}

Kemitraan yang di gagas oleh bank Indonesia melalui Linkage Program merupakan program kerjasama antara perbankan komersial dengan BPR/S atau Lembaga Keuangan mikro syari'ah untuk pembiayaan pada sektor KUKM. Program yang digulirkan sejak tahun 2005 ini, direspon secara baik oleh pihak bank syari'ah dalam rangka perluasaan jaringan BPR/S dan lembaga keuangan mikro syari'ah seperti Baitul Maal Wa Tamwil (BMT). Dari data Outlook Perbankan Syari'ah yaitu 8 BUS dan 4 UUS yang melaporkan pelaksanaan linkage program, jumlah dana yang disalurkan perbankan syari'ah selama tahun 2012 (s.d Oktober 2012) adalah linkage program BPRS sebesar Rp. 207,2 Milyar dan BMT Rp. 439,2 milyar. 
Linkage program ${ }^{1}$ merupakan sebuah strategi yang bertujuan memberdayakan dan memberikan akses permodalan usaha kecil serta menengah melalui pelibatan partisipasi dalam industri keuangan. Hal ini didasarkan atas fakta bahwa BPR/S atau lembaga keuangan mikro syari'ah seperti Baitul Maal Wa Tamwil (BMT) terkadang mendapatkan masalah dalam melakukan mobilisasi dana disektor publik. Sedangkan dipihak lain bank komersial cenderung memiliki dana yang berlebih disektor publik (over likuiditas) tetapi ruang untuk menjangkau bisnis mikro terbatas ruang geraknya. Dengan kata lain bahwa benefit dari program ini, perbankan komersial mendapatkan kemudahan akses terhadap KUKM dan BMT mendapatkan keuntungan dari ketersediaan dana untuk disalurkan pada debitor, dengan tetap memperhatikan proses manajemen resiko sehingga tidak mendorong terjadinya peningkatan rasio pembiayaan bermasalah (non performing financing), karena sesungguhnya resiko akan dibebankan kepada pihak penerima program yaitu BMT.

Skema linkage program yang dilakukan bank syari'ah dengan BPR/S atau BMT dapat berupa channeling, executing atau joint financing. Skema channeling menempatkan BPR/S atau BMT sebagai intermediator BUS/UUS dengan pelaku UMKM. Sedangkan skema executing dilakukan ketika BUS/UUS menyediakan pembiayaan yang didapat oleh BPR/S atau BMT dalam pembiayaan ke nasabah UMKM nya. Sedangkan Joint Financing skema dimana BUS/UUS dan BPR/S atau BMT bekerjasama dalam memberikan pembiayaan pada pelaku UMKM.

Permasalahan yang dialami UMKM tersebut antara lain yaitu 1) rendahnya produktifitas, 2) terbatasnya akses UMKM kepada sumberdaya produktif terutama akses permodalan, teknologi, informasi dan pasar, 3) kurang kodusifnya iklim usaha. ${ }^{2}$ Permasalahan terbatasnya akses UMKM kepada sumberdaya produktif, dapat kita lihat dalam hal pendanaan, produk jasa lembaga keuangan sebagian besar masih berupa kredit modal kerja, sedangkan untuk kredit investasi sangat terbatas, sehingga sulit meningkatkan

${ }^{1}$ Linkage Program adalah kerjasama penyaluran dana dari bank umum kepada atau melalui BPR/BPRS dalam rangka pembiayaan kepada nasabah mikro dan kecil. Lihat Euis Amalia, Keadilan Distributif dalam Ekonomi Islam: Penguatan Peran LKM dan UKM, hal. 309 $279-280$

2 Rencana Pembangunan Jangka menengah Nasional Tahun 2004-2009, cet. Pertama, hal. 
kapasitas usaha. Disisi lain persyaratan pinjaman/pembiayaan yang tidak mudah untuk dipenuhi bagi UMKM, meskipun usahanya dinilai layak tetapi jumlah jaminan yang ada harus memadai dan cukup menurut penilaian bank,dan masalah lainnya dunia perbankan yang merupakan sumber pendanaan terbesar bagi UMKM ' ${ }^{3}$, disamping peran sebagai lembaga intemediasi antara penyimpan dan peminjam dana. ${ }^{4}$

Berdasarkan data Bank Indonesia 5 , dari jumlah bank secara keseluruhan yang menjalankan fungsi intermediasi per Januari 2010 yakni 121 bank-terdiri dari 4 bank Persero (state owned banks), 35 BUSN Devisa (Foreign Exchange Commercial Bank), 30 BUSN Non Devisa (Non Foreigh Exchange Comercial Banks), 26 BPD (Regional Development Banks), 16 Bank Campuran (Joint Venture Banks), 10 Bank Asing (Foreighn Owned Banks), Tingkat LDR (Loan to Deposit Ratio) bank Umum yang lebih dari sama dengan 50\% hanya 108 Bank. Sedangkan sisanya 13 bank memilki LDR (Loan Deposit Ratio) kurang dari 50\%.Kinerja Bank Umum secara keseluruhan per Januari 2010 sebesar 72,13\%, kredit yang disalurkan hanya sebesar 1.405.640 Miliar dari 1.948.890 Miliar dana pihak ketiga (DPK) yang berhasil dihimpun, berarti Non Performing Loan (nominal) Bank Umum per Januari 2010 sebesar 48.830 Miliar atau sekitar 3,47\%. ${ }^{6}$

Berdasarkan latar belakang diatas, penulis tertarik untuk membahas lebih lanjut tentang hubungan hukum kemitraan dalam program linkage sudah menguntungkan kedua belah pihak antara bank dan BMT, sehingga konsep kemitraan dibangun berdasarkan asas mutualisme khususnya bagi BMT yang merupakan pihak yang langsung berhadapan dengan nasabah pembiayaan atau sebagai pihak penanggung resiko terhadap kredit macet dan banyak lagi persoalan yang muncul ketika kemitraan berjalan ada salah satu pihak yang lebih kuat atau mempunyai informasi yang lebih banyak ketimbang pihak lain (assymetric information), belum lagi masalah hukum yang menjadi landasan operasional bagi program kemitraan.

\footnotetext{
${ }^{3}$ Ibid, hal. 280

4 A.Riawan Amin, Perbankan Syariah sebagai Solusi Perekonomian Nasional, Pidato Penganugerahan Gelar Doktor Honoris Causa dalam Bidang Perbankan Syari'ah, Sidang senat Terbuka UINSyarif Hidayatullah Jakarta, Sabtu 11 Juli 2009

${ }_{5}^{5}$ Bank Indonesia, Statistika Perbankan Indonesia Januari 2010: Tabel 1.85 Perkemabngan jumlah Bank dan Kantor Bank Umum (Growth of Total Bank and Bank Offices), hal. 88

${ }^{6}$ Ibid, hal 25
} 
Hubungan Hukum Kemitraan dalam Linkage Program

\section{Manfaat Kemitraan Perbankan}

Pertanyaan yang mendasar dalam kemitraan adalah adakah manfaat kemitraan bank dan lembaga lain untuk mendukung Pemberdayaan UMKM ? jawabnya sangat bermanfaat karena UMKM sangat membutuhkan modal, sedangkan bank adalah lembaga yang lahir sebagai agent of trust and agent development. Agent of trust adalah suatu lembaga perantara (intermediary) yang dipercaya untuk melayani segala kebutuhan dari dan untuk masyarakat. Sedangkan Agent development, bank adalah sebagai lembaga perantara yang dapat mendorong kemajuan pembangunan melalui fasilitas pembiayaan dengan kemudahan pembayarannya serta penarikan dalam proses transaksi bagi pelaku ekonomi (UMKM). Dengan demikian keduanya baik UMKM dan bank sebenarnya bisa berkerjasama secara sinergis dan alasan inilah menjadi salah satu dasar perlunya kemitraan perbankan dengan lembaga lain, disamping beberapa alasan lain. Yaitu :

Pertama, sangat minimnya akses permodalan, maka perlu diberdayakan dan dibuka akses permodalan UMKM. Kedua, jumlah UMKM yang besar, jika pelaku UMKM tidak diberdayakan akan menyebabkan jurang kemiskinan makin mengangga lebar dan akan menciptakan beban Negara karena angka kriminalitas akibat pengangguran semakin besar. Ketiga, Jika UMKM diberdayakan secara tepat sasaran akan berkembang mempercepat akselerasi pertumbuhan UMKM dari usaha kecil kemudian menjadi usaha menenggah. Dan keempat, kalau UMKM mendapat suntikan pembiayaan dari perbankan akan semakin cepat akselerasi berkembangnya.Akan tetapi UMKM juga harus ada pendampingan terhadap keterbatasan akses pemasaran, kompetisi networking usaha yang masih lemah, sehingga perlu pendampingan yang harus di lakukan secara integral dan kesatuan yang utuh dalam melaksanakan kemitraan.

Pola kemitraan perbankan untuk UMKM salah satunya adalah pola hubungan executing yaitu pihak pelaksana bertanggung jawab terhadap resiko tunggakan pokok dan bagi hasil. Pelaksana dalam kemitraan bank dan UMKM yaitu Baitul maal watamwil (BMT) atau badan lain yang ditunjuk Menteri Keuangan seperti BMT, BPRS atau lembaga keuangan non syariah. 
Johan Arifin

\section{Hubungan Hukum Kemitraan}

Pola hubungan hukum Linkage program yang dilakukan kepada BPR/S atau BMT mempunyai beberapa landasan strategis. Pertama, dilakukan dengan mekanisme bagi hasil dan mengharamkan riba sehingga terwujud pola kemitraan yang lebih adil dan menguntungkan semua pihak. Kedua, jaringan BPR/S dan BMT yang luas. Ketiga, BPR/S dan BMT mudah diakses oleh masyarakat berpendapatan rendah. Keempat, pengalaman BPR/S dan BMT melayani nasabah kecil membuat keduanya mempunyai keunggulan spesialisasi dibandingkan bank syari'ah dalam menggarap segmentasi UMKM.

Kerjasama kemitraan terlaksana karena melihat beberapa aspek, yaitu 1) Kepercayaan, kepercayaan yang merupakan asas dasar dalam kesepakatan kemitraaan.Kepercayaan menjadi sangat penting karena dua alasan. Pertama,Karena hubungan hukum jangka panjang dan setiap pihak harus mempunyai komitmen berdasarkan integritas dan keandalan. Kedua, pada tahap konseptual nasabah harus mau membuka informasi yang bersifat rahasia. Inilah yang kadang -kadang berat bagi UMKM dan inilah yang disebut assymetric information (salah satu pihak mempunyai informasi yang lebih banyak ketimbang pihak lain).Dalam rangka meningkatkan fungsi intermediasi perbankan dan memperluas penyaluran pembiayaan oleh perbankan, maka bank Indonesia membuat kebijakan linkage program yang merupakan perluasan pola pembiayaan perbankan dengan membangun kerjasama kemitraan dengan lembaga keuangan lainnya, baik BPR/S, BMT, Koperasi dan lembaga keuangan lainnya.

Daftar Bank Umum pelaku penandatangan Linkage program pada tahun 2009 tercatat sebanyak 19 bank umum diantaranya adalah PT. Bank Muamalah Indonesia sebesar Rp. 66.586.747.138 (mitra program BPRS dan BMT), PT. Bank Syari'ah Mandiri sebesar Rp. 27.000.000.000,- (mitra program BPR dan BPRS), PT. Bank Negara Indonesia (Persero) Tbk sebesar Rp. 512.000.000.000,- (mitra program BPR dan Koperasi), dan PT. Bank Mega Tbk sebesar Rp. 15.000.000.000,- (mitra program BPR). Total Plafon kredit linkage program (BPR/S) periode Juli 08 Maret 2009 (16 Bank Umum) sebesar Rp. 1.538.000.000.000,-, sedangkan total plafon kedit linkage program (koperasi, 
BMT) periode Juli 08 Maret 2009 (12 Bank Umum) sebesar Rp. 1.928.000.000.000,-7

Hubungan hukum kemitraan kalau dilihat dalam prespektif muamalah dan hukum positif, maka hubungan hukum yang terjadi di perbakan syari'ah tercermin dalam kontrak yang dibuatnya atau dengan kata lain terjadinya sebuah kontrak (kemitraan) adalah hasil dari kesepakatan kedua belah pihak tanpa adanya keterpaksaan, sehingga hubungan hukum kemitraan terletak pada akad-akad yang dibuatnya dan meruapkan peristiwa hukum yang terjadi karena perbuatan hukum. Perbuatan hukum dalam kemitraan linkage program dialkukan dengan perjanjian/ akad. Akad dalam pengertian ini dalam bahasa arab berarti ikatan atau simpulan baik ikatan yang Nampak (bissy) maupun tidak tampak (ma'nawy) Kamus al-Mawardi menterjemahkan al-'Aqd sebagai contract and agreement atau kontrak dan perjanjian yang memiliki implikasi hukum yang mengikat. ${ }^{8}$

Asas keadilan yang merupakan salah satu tujuan dari hukum selain dari kepastian hukum itu sendiri dan juga kemanfaatan hukum. Namun dalam khasanah filsafat hukum sampai sekarang masih menjadi perdebatan tentang apa makna adil. Keadilan itu sendiri terkait dengan pendistribusian yang merata antara hak dan kewajiban manusia. ${ }^{9}$ Satjipto Raharjo dalam bukunya Ilmu Hukum mengatakan hukum melindungi seseorang dengan cara mengalokasikan suatu kekuasaan kepadanya untuk bertindak dalam rangka kepentingganya tersebut. Pengalokasian kekuasaan ini dilakukan secara terukur, dalam arti ditentukan kekuasaan dan kedalamannya, kekuasaan yang demikian yang disebut dengan hak,sehingga antara kedua pihak harus ada keseimbangan hak dan kewajiban. Pendapat senada juga disampaikan Wiryono Prodjodikoro $^{10}$ hukum adalah serangkaian peraturan-peraturan mengenai tingkah laku orang-orang sebagai anggota suatu masyarakat dan bertujuan

\footnotetext{
${ }^{7}$ Bank Indonesia, "Lampiran Siaran Pres N0.11/11/PSHM/Humas : Daftar Bank Umum Pelaku Penandatanganan Linkage Program pada Rabu, 1 April 2009”, diakses dari http://www.bi.go.id/web/id/ruang +Media/Siaran+Pres/sp 111109. htm, hal 1

8 Johan Arifin, Hubungan Hukum antara Nasabah dan Lembaga Keuangan Mikro syariah, hasil penelitian fakultas Syariah IAIN Walisongo Semarang, DIPA, 2010 hlm. 63

${ }^{9}$ Muhsin, Nilai-Nilai Keadilan, t. tahun. h. 1.( selanjutnya disingka Mubsin II )

10 Satjipto Raharjo, Ilmu hukum, PT. Citra Aditya, Bandung, 2000, hlm. 53 Lihat juga Wiryono Prodjodikoro, Hukum Perdata tentang Persetujuan-persetujuan tertentu, Bandung:Sumur,1981 hal. 17
} 
mengadakan tata tertib diantara para anggota masyarakat. Hukum perdata dipercaya untuk mengatur hubungan antar individu dalam masyarakat. Hukum perdata menciptakan kepastian hukum melalui aturan-aturan umum yang dapat dituntut penegakannya dimuka hakim perdata dan mengandung sanksi-sanksi untuk memberikan perlindungan kepada pihak ketiga.

Asas keadilan dalam prespektif hukum Islam sering kita sebut dengan maqashid syariah yang menegaskan bahwa hukum islam disyariatkan untuk mewujudkan dan memelihara maslahah umat manusia " dimana ada maslahat, disana terdapat hukum Allah"11. Teori maslahat ini menurut Masdar F. Masudi ${ }^{12}$ sama dengan teori keadilan sosial dalam istilah filsafat hukum yaitu menghindari keburukan atau menarik manfaat dan menolak mudarat, istilah yang sepadan dengan inti dari maqashid al-syariah tersebut adalah maslahah. Jadi dengan demikian bahwa hubungan kemitraan harus berlandaskan kemaslahatan terdahap pihak-pihak yang bermitra yaitu bank dan lembaga keuangan mikro syari'ah seperti BMT serta memberikan maslahah pula kepada nasabah.

Hakekat hukum merupakan alat atau sarana untuk mengatur dan menjaga ketertiban guna mencapai suatu masyarakat yang berkeadilan dalam menyelenggarakan kesejahteraan sosial yang berupa peraturan yang bersifat memaksa dan memberikan sanksi bagi yang melanggarnya, baik itu untuk mengatur masyarakat ataupun aparat pemerintah sebagai penguasa. Konsep dasar itu sesungguhnya berbicara pada dua aspek persoalan :

1. Aspek yang pertama adalah keadilan yang menyangkut tentang kebutuhan masyarakat akan rasa adil ditengah sekian banyak dinamika dan konflik di tengah masyarakat, maka hubungan hukum kemitraan dalam program linkage harus menjunjung aspek keadilan yaitu BMT sebagai pelaksana program yang harus berhadapan dengan nasabah langsung harus mempunyai informasi dan kedudukan yang seimbang dengan lembaga keuangan pemberi program linkage, dengan demikian

11 Muhammad Sa'id Ramdan al-Buti, Dawabit al-Maslabah fi as-Syariah al-islamiyah, Beirut : Mu"assasah ar-Risalah, 1997 hlm 12

12 Masdar F. Mas'udi, "Meletakkan Kembali Maslahat Sebagai Acuan Syari'ab", Jurnal Ilmu dan Kebudayaan Ulumul Qur'an No. 3, Vol. VI Th. 1995, Hlm 97 
apabila terjadi kredit macet dan masalah lain muncul di nasabah UMKM menjadi tanggung jawab bersama.

2. Aspek yang kedua adalah aspek legalitas menyangkut apa yang disebut dengan hukum positif, yaitu sebuah aturan yang ditetapkan oleh sebuah kekuasaan Negara yang sah dan dalam pemberlakuannya dapat dipaksakan atas nama hukum. Dalam hal ini harus ada kejelasan secara hukum hak dan kewajiban antara pihak lembaga keuangan yang saling menjalankan kemitraan, sehingga manakala terjadi kasus-kasus hukum maka legalitas hukumnya jelas.

Kejelasan dalam legalitas hukum kemitraan tercermin di perjanjian, sebagaimana diatur dalam buku III Burgelijk Wetboek (BW), bahwa perjanjian adalah salah satu bagian penting dari hukum perdata ${ }^{13}$ didalamnya diterangkan mengenai perjanjian khusus yang dikenal oleh masyarakat seperti jual beli, sewa menyewa, dan perjanjian pinjam meminjam. Burgelijk Wetboek (BW) mengenal sistem terbuka dalam hukum perjanjian. Sistem terbuka adalah bahwa setiap orang atau sekelompok orang boleh membuat perjanjian apa saja asalkan tidak bertentangan dengan ketertiban umum dan kesusilaan. Sistem terbuka yang mengandung kebebasan membuat suatu perjanjian dapat disimpulkan dari pasal 1338 ayat 1 BW yang berbunyi :

"semua perjanjian yang dibuat sah berlaku sebagai undang-undang bagi mereka yang membuatnya".

Pasal ini menunjukan kepada setiap orang atau lembaga untuk melakukan perjanjian apa saja. Dengan menekankan pada kata "semua" menunjukan bahwa semua orang atau sekelompok orang atau lembaga diperbolehkan untuk membuat perjanjian yang berisi apa saja dan berupa apa saja dan perjanjiaan tersebut mengikat yang membuatnya seperti suatu undangundang $^{14}$. Ada hal yang sangat fundamental sifatnya untuk diperhatikan didalam pembuatan suatu perjanjian kemitraan, terutama terkait dengan asas hukum.

${ }^{13}$ F. Tangker,1993, Hukum Suatu Pendekatan Elementer, Nova,Bandung, hal. 30

14 R. Subekti, 1991, Hukum Perjanjian, PT.internusa, Jakarta, hal. 14 
Tentang asas hukum ini Paull Scolten ${ }^{15}$ berpendapat asas hukum adalah pikiran-pikiran dasar yang terdapat didalam dan belakang sistem hukum masing yang dirumuskan dalam aturan-aturan perundang-undangan, selanjutnya Paull Scolten juga berpendapat asas khusus yang terdapat dalam kemitraaan yaitu berupa asas kekebesan berkontrak, asas konsensualisme, asas iktikad baik, asas kepercayaan, asas kesetaraan. Senada dengan pendapat R. Setiawan yang mengatakan bahwa suatu perjanjian harus ada kata sepakat kedua belah pihak karena perjanjian merupakan perbuatan hukum bersegi dua atau jamak. Berbeda dengan perjanjian bersegi satu, tidak perlu adanya kata sepakat kedua belah pihak. Perjanjian adalah perbuatan-perbuatan yang untuk terjadinya disyaratkan adanya kata sepakat antara dua orang atau lebih, jadi merupakan persetujuan ${ }^{16}$. Keharusan adanya kata sepakat dalam hukum perjanjian dikenal dengan asas konsensualisme.

Asas ini merupakan dasar perjanjian dan perikatan, karenanya perjanjian sudah dilahirkan sejak detik tercapainya kata sepakat ${ }^{17}$. Dalam BW pasal 1320 disebutkan bahwa untuk sahnya suatu perjanjian diperlukan empat syarat yang meliputi : “(1) sepakat mereka mengikatkan dirinya; (2) kecakapan untuk membuat suatu perjanjian; (3) suatu hal tertentu; (4) suatu sebab halal. Dua syarat pertama disebut dengan syarat subyektif, sedangkan syarat ketiga dan keempat disebut syarat obyektif.

Secara garis besar terdapat dua jenis akad yang berlaku dalam industri perbankan syari'ah. Yaitu akad tabarru' dan akad tijarah. Akad tabarru' merupakan akad atau perjanjian yang tujuan utamanya hanya keinginan untuk saling tolong menolong semata. Pihak-pihak yang terlibat dalam akad seperti ini tidak dapat mengambil keuntungan sedikitpun karena hanya mengharapkan balasan dari Tuhan Yang Maha Esa. Akan tetapi salah satu pihak dapat mengenakan biaya sekadar menutupi biaya yang muncul akibat transaksi ${ }^{18}$.

\footnotetext{
${ }^{15}$ Paul Scholten didalam JJ. H. Bruggink, Refleksi Hukum (alih bahasa oleh Arif Sidharta) PT. Cipta Aditya Bakti Bandung, hlm 119-120

${ }^{16}$ R. Setiawan, 1987, Pokok-pokok Hukum Perikatan, Bina Cipta, Bandung, hal.12

${ }^{17}$ R. Subekti, HukumPerjanjian. Op.Cit, Bandung, hal. 15

18 Sunarto Zulkifli, 2003, Panduan Praktis Transaksi Perbankan Syariah, Jakarta: Zikrul Hakim, hal., 13
}

Volume IV/Edisi 2/November 2013 


\section{Bentuk-Bentuk Kemitraan pada Linkage Program}

Kemitraan ini dengan ada 3 (tiga) bentuk yaitu channeling, Executing, dan Joint Financing. Channeling adalah pembiayaan yang diberikan oleh bank umum syariah kepada nasabah koperasi/KJKS/ BMT dan BMT yang bertindak sebagai agen yang tidak mempunyai kewenangan memutus pembiayaan kecuali mendapatkan surat kuasa dari bank umum. Pencataan di Bank Umum sebagai pembiayaan kepada nasabah BMT, sedangkan pencataan di BMT pada off balance sheet..

Executting adalah pembiayaan yang diberikan oleh bank umum syari'ah kepada koperasi/KJKS/BMT dalam rangka pembiayaan untuk disalurkan kepada nasabah BMT, dimana koperasi/KJKS/BMT memiliki kewenangan memutus pembiayaan ke UMKM. Pencatatan di Bank umum syariah sebagai pembiayaan kepada nasabah BMT, sedangkan pencatatan di koperasi sebagai pinjaman kepada nasabah BMT.

Joint financing adalah pembiayaan bersama oleh bank umum syariah dan koperasi terhadap angota koperasi. Kewenangan memutus pembiayaan ada pada BUS/UUS dan KJKS/BMT. Pencatatan outstanding credit bagian bank umum dan koperasi sebesar porsi pembiayaan kepada anggota koperasi.

Pola Kemitraan yang sudah berjalan, bukan tidak mungkin menyisakan beberapa masalah, diantaranya kewajiban BPR/S dan BMT diwajibkan menyerahkan data nasabahnya sehingga dimungkinkan nasabah yang potensial bisa diambil alih oleh bank yang diajak kerjasama (channeling), dan terjadinya ketidakadilan antara bank umum syari'ah dan koperasi/KJKS/BMT yang secara operasional melakukan pengawasan dan pendampingan bersama, akan tetapi keuntungan/bagi hasil yang diberikan lebih besar kepada bank. ${ }^{19} \mathrm{Hal}$ ini sangat dirasakan oleh BMT selaku penerima dana di program tersebut dan bisa jadi keberlangsungan pola kemitraan akan memunculkan masalah dikemudiaan hari, sehingga perlu ada formulasi terhadap pola kemitraan yang sudah berjalan agar ditemukan pola kemitraan yang menguntungkan dan berkeadilan bagi kedua belah Bank dan BMT, karena kemitraan perlu menjadikan etika bukan karena being with other melainkan karena being for other (relasi asimetri). Artinya manusia hidup bukan karena bersama orang lain, melainkan ia juga hidup

${ }^{19}$ Hasil observasi dan pantauan dilapangan antara bank dan BMT di Jawa Tengah 
untuk orang lain. Dan tentunya hal itu membutuhkan satu bentuk aturan (etika) yang sesuai agar interaksi bisa berjalan dengan baik.

\section{Kesimpulan}

Dari penjelasan diatas, penulis menyimpulkan, antara lain :

1. Pelaksanaan Linkage program merupakan sebuah strategi yang bertujuan memberdayakan usaha kecil serta menengah melalui pelibatan partisipasi industri keuangan. Hal ini didasarkan atas fakta bahwa BPR/S atau lembaga keuangan mikro syari'ah seperti Baitul Maal Wa Tamwil (BMT) terkadang mendapatkan masalah dalam melakukan mobilisasi dana disektor publik. Sedangkan pada bank komersial cenderung memiliki dana yang berlebih disektor publik (over likuiditas) tetapi tidak bisa menjangkau bisnis mikro.

2. Masih ada kekhawatiran sebagai lembaga pelaksana seperti BMT yaitu kewajiban BMT diwajibkan menyerahkan data nasabahnya sehingga dimungkinkan nasabah yang potensial bisa diambil alih oleh bank yang diajak kerjasama (channeling), dan terjadinya ketidakadilan antara bank dan BMT yang secara operasional melakukan pengawasan dan pendampingan bersama, akan tetapi keuntungan/bagi hasil yang diberikan lebih besar kepada bank.

3. Pola kemitraan dalam perbankan syariah ada 3 (tiga) bentuk yaitu pola channeling, executing, dan joint financing, yang ketiga pola kemitraan tersebut masih perlu formulasi agar kesetaraan tanggungjawab terhadap pendampingan sehingga meminimalisir terhadap UMKM yang mengalami masalah baik masalah manajemen akses pasar dan permodalam, sehingga UMKM yang bermasalah dapat ditangani lebih cepat karena kejelasan wewenang dan antara bank dan BMT. 
Hubungan Hukum Kemitraan dalam Linkage Program

\section{DAFTAR PUSTAKA}

A.Riawan Amin, Perbankan Syari'ah sebagai Solusi Perekonomian Nasional, Pidato Penganugerahan Gelar Doktor Honoris Causa dalam Bidang Perbankan Syari'ah, Sidang senat Terbuka UIN Syarif Hidayatullah Jakarta,

Bank Indonesia, Statistika Perbankan Indonesia Januari 2010: Tabel 1.85 Perkemabngan jumlah Bank dan Kantor Bank Umum (Growth of Total Bank and Bank Offices),

Bank Indonesia, "Lampiran Siaran Pres N0.11/11/PSHM/Humas : Daftar Bank Umum Pelaku Penandatanganan Linkage Program pada Rabu, 1 April 2009", diakses dari http://www.bi.go.id/web/id/ruang +Media/Siaran+Pres/sp 111109.

Euis Amalia, Keadilan Distributif dalam Ekonomi Islam: Penguatan Peran LKM dan UKM,

F. Tangker,1993, Hukum Suatu Pendekatan Elementer, Nova,Bandung,

Paul Scholten didalam JJ. H. Bruggink, Refleksi Hukum (alih bahasa oleh Arif Sidharta) PT. Cipta Aditya Bakti Bandung,

R. Subekti, 1991, Hukum Perjanjian, PT.internusa, Jakarta

R. Setiawan, 1987, Pokok-pokok Hukum Perikatan, Bina Cipta, Bandung

R. Setiawan, 1987, Pokok-pokok Hukum Perikatan, Bina Cipta, Bandung

Masdar F. Mas'udi, "Meletakkan Kembali Maslahat Sebagai Acuan Syari'ab", Jurnal Ilmu dan Kebudayaan Ulumul Qur'an No. 3, Vol. VI Th. 1995

Muhammad Sa'id Ramdan al-Buti, Dawabit al-Maslahah fi as-Syariah al-islamiyah, Beirut: Mu"assasah ar-Risalah,

Sunarto Zulkifli, 2003, Panduan Praktis Transaksi Perbankan Syariah, Jakarta: Zikrul Hakim, hal., 13

Satjipto Raharjo, Ilmu hukum, PT. Citra Aditya, Bandung, 2000, hlm. 53 Lihat juga Wiryono Prodjodikoro, Hukum Perdata tentang Persetujuanpersetujuan tertentu, Bandung:Sumur, 1981

Wiryono Prodjodikoro, 1981, Hukum Perdata tentang Persetujuan-persetujuan tertentu, Bandung:Sumur, 